\title{
ETV6/MDS2 Fusion Gene
}

National Cancer Institute

\section{Source}

National Cancer Institute. ETV6/MDS2 Fusion Gene. NCI Thesaurus. Code C99409.

A fusion gene that results from a chromosomal translocation $t(1 ; 12)(p 36 ; p 13)$ which fuses exons 1 and 2 of the ETV 6 gene to exons 6 and 7 of the MDS2 gene. This fusion may be associated with myeloid disorders. 